\begin{tabular}{|l|l|l|}
\hline \multicolumn{2}{|c|}{ PublisherInfo } \\
\hline \hline PublisherName & $:$ & BioMed Central \\
\hline \hline PublisherLocation & $:$ & London \\
\hline \hline PublisherImprintName & $:$ & BioMed Central \\
\hline \hline
\end{tabular}

\title{
Controlling the cell cycle clock
}

\begin{tabular}{|l|l|l||}
\hline \multicolumn{2}{|c|}{ ArticleInfo } \\
\hline \hline ArticleID & $:$ & 4227 \\
\hline \hline ArticleDOI & $:$ & $10.1186 /$ gb-spotlight-20011017-01 \\
\hline \hline ArticleCitationID & $:$ & spotlight-20011017-01 \\
\hline \hline ArticleSequenceNumber & $:$ & 298 \\
\hline \hline ArticleCategory & $:$ & Research news \\
\hline \hline ArticleFirstPage & $:$ & 1 \\
\hline \hline ArticleLastPage & $:$ & 3 \\
\hline \hline & $:$ & RegistrationDate : 2001-10-17 \\
ArticleHistory & $:$ & OnlineDate $\quad$ 2001-10-17 \\
\hline \hline ArticleCopyright & $:$ & BioMed Central Ltd2001 \\
\hline \hline ArticleGrants & $:$ & \\
\hline \hline ArticleContext & $:$ & 130592211 \\
\hline \hline
\end{tabular}


Susan Aldridge

Email: SusAldr@cs.com

LONDON - The award of the 2001 Nobel Prize for Physiology or Medicine to Leland Hartwell, Tim Hunt and Paul Nurse for discoveries in cell cycle control follows an article in 21 September Cell by Itamar Simon and colleagues at the Whitehead Institute, Cambridge, Massachusetts outlining a further important advance in this field. Richard A. Young and his team have learned how the regulators of the cell cycle are themselves regulated, using a new technique for studying DNA-protein binding in vivo.

The regulation of cell division by the co-ordinated control of the cell cycle clock through its various stages is essential to the healthy functioning of all organisms - from bacteria to humans. Loss of cell cycle control plays an important role in cancer, and its restoration is currently the target of potential new therapeutics.

Many of the proteins involved in cell cycle control are already known; in humans, for instance, the cyclin dependent kinases (CDKs) regulate different phases of the cell cycle through reversible phosphorylation that is, in itself, controlled by another group of proteins, known as cyclins. But what has not previously been well understood is how the regulators of the cell cycle are themselves transcriptionally regulated - so the map of the cell cycle has been incomplete.

The Whitehead team studied nine cell cycle transcription activators in yeast, each of which was known to be involved in turning on genes needed for specific stages of the cycle. What they found somewhat to their surprise - was that each of the activators also acted as a bridge to the next stage, turning on transcription of the corresponding regulator involved in the next stage of the cycle. This means that the cell cycle regulators - the 'master switches' - form their own closed circuit ensuring smooth running of the cell cycle clock. The challenge now is to construct a complete map of the cell cycle, including all the levels of control.

The current study made use of a new technique for studying DNA-protein binding called genomewide location analysis, which was developed in Young's lab. This involves fixing DNA-binding proteins to their binding sites in vivo, using chemical cross-linking, and then fishing out protein-bound DNA fragments with antibody-linked magnetic beads following cell cleavage. After unhooking the proteins, the DNA fragments that were bound to the transcription activators were identified by hybridization against a yeast library in an array.

"We think a key aspect of our study is this novel use of a microarray for locating the actual physical binding of transcription factors on the genome," commented Tom Volkert, one of Young's co-workers. "We hope to go on from here to construct other networks for transcription regulators which will resemble the more familiar metabolic pathways used by biochemists."

The team is now constructing a detailed network map of cell cycle regulation in yeast, and will publish a study similar to the current one on the human cell cycle in the near future. Such advances are likely to be of interest to the pharmaceutical industry, as attention shifts from the genome itself to the proteins it codes for and their interacting pathways in the cell. 


\section{References}

1. The 2001 Nobel Prize for Physiology or Medicine, [http://www.nobel.se/medicine/laureates/2001/ press.html]

2. Simon I, Barnett J, Hannett B, Harbison CT, Rinaldi NJ, Volkert TL, Wyrick JL, Zeitlinger J, Gifford DK, Jaakkola TS, et al.: Serial regulation of transcriptional regulators in the yeast cell cycle. Cell 2001, 106:697-708., [http://www.cell.com/content/vol106/issue6/]

3. The Whitehead Institute, [http://www.wi.mit.edu]

4. The Young Laboratory, [http://web.wi.mit.edu/young/cellcycle]

5. Nurse P: A long twentieth century of the cell cycle and beyond. Cell 2000, 100:71-78., [http://www.cell.com/content/vol100/issue1]

6. Ren B, Robert F, Wyrick JJ, Aparicio O, Jennings EG, Simon I, Zeitlinger J, Schreiber J, Hannett N, Kanin E, et al:: Genome-wide location and function of DNA binding proteins. Science 2000, 290:2306-2309., [http://www.sciencemag.org/cgi/content/abstract/290/5500/2306] 